\title{
Toxicity of six plant extracts and two pyridone alkaloids from Ricinus communis against the malaria vector Anopheles gambiae
}

Sabina Wangui Wachira ${ }^{1,2^{*}}$, Sabar Omar ${ }^{3}$, Julia Wanjiru Jacob ${ }^{1}$, Martin Wahome ${ }^{4}$, Hans T Alborn ${ }^{5}$, David R Spring ${ }^{6}$, Daniel K Masiga ${ }^{1}$ and Baldwyn Torto ${ }^{1 *}$

\begin{abstract}
Background: The African malaria vector, Anopheles gambiae s.S., is known to feed selectively on certain plants for sugar sources. However, the adaptive significance of this behaviour especially on how the extracts of such plants impact on the fitness of this vector has not been explored. This study determined the toxicity and larvicidal activity on this vector of extracts from six selected plants found in Kenya and two compounds identified from Ricinus communis: 3-carbonitrile-4-methoxy-N-methyl-2-pyridone (ricinine), and its carboxylic acid derivative 3-carboxy-4methoxy-N-methyl-2-pyridone, the latter compound being reported for the first time from this plant.

Methods: Feeding assays tested for toxic effects of extracts from the plants Artemisia afra Jacq. ex Willd, Bidens pilosa L., Parthenium hysterophorus L., Ricinus coummunis L., Senna didymobotrya Fresen. and Tithonia diversifolia Hemsl. on adult females and larvicidal activity was tested against third-instar larvae of Anopheles gambiae s.S. Mortality of larvae and adult females was monitored for three and eight days, respectively; Probit analysis was used to calculate $L C_{50}$. Survival was analysed with Kaplan-Meier Model. LC-MS was used to identify the pure compounds.

Results: Of the six plants screened, extracts from $T$. diversifolia and $R$. communis were the most toxic against adult female mosquitoes after 7 days of feeding, with $L C_{50}$ of 1.52 and $2.56 \mathrm{mg} / \mathrm{mL}$ respectively. Larvicidal activity of all the extracts increased with the exposure time with the highest mortality recorded for the extract from $R$. communis after $72 \mathrm{~h}$ of exposure ( $\left(\mathrm{C}_{50} 0.18 \mathrm{mg} / \mathrm{mL}\right.$ ). Mosquitoes fed on solutions of the pure compounds, 3-carboxy-4-methoxy$\mathrm{N}$-methyl-2-pyridone and ricinine survived almost as long as those fed on the $R$. communis extract with mean survival of $4.93 \pm 0.07,4.85 \pm 0.07$ and $4.50 \pm 0.05$ days respectively.

Conclusions: Overall, these findings demonstrate that extracts from the six plant species exhibit varying bioactivity against the larvae and adult females of An. gambiae s.s. T. diversifolia and R. communis showed highest bioactivity against adult females An. gambiae and larvae while longevity of female An. gambiae s.s. decreased with exposure time to the two pure compounds.
\end{abstract}

Keywords: Anopheles gambiae s.s, Malaria, Mosquito, Alkaloid, Larvicidal, Toxicity, Ricinus coummunis, Tithonia diversifolia

\footnotetext{
* Correspondence: swachira2013@gmail.com; btorto@icipe.org

IInternational Centre of Insect Physiology and Ecology, P.O. Box

30772-00100, Nairobi, Kenya

${ }^{2}$ Kenya Medical Research Institute, Centre for Traditional Medicine and Drug

Research, P. O. Box 54840-00200, Nairobi, Kenya

Full list of author information is available at the end of the article
} 


\section{Background}

Malaria remains a life-threatening disease caused by parasites that are transmitted to humans through the bites of certain species of infected anopheline mosquitoes [1]. The WHO global estimates document about 207 million cases of malaria and an estimated 627,000 deaths in 2012 [1]. Most malaria-related deaths occur in children under 5 years of age in sub-Saharan Africa [1]. The high mortality burden persists under the backdrop of rising resistance to standard anti-malarials especially by Plasmodium falciparum, the most widespread etiological agent for human malaria. In fact, currently, malaria treatment is threatened by resistance to all anti-malaria drugs including artemisinin-based combination therapies [2-5], the first line treatment for $P$. falciparum malaria. Therefore, continued efforts to develop alternative therapies are necessary.

The principal vector of $P$. falciparum in sub-Saharan Africa is An. gambiae Giles s.s. [6,7]. Knowledge of the vector's interaction with plants can lead to the development of new malaria control tools. Plant feeding influences important aspects in the life cycle of malaria vectors such as their survival and reproductive success. After emergence, both males and females almost exclusively feed on plant-derived sugary fluids including sap, nectar, and honeydew in order to supplement their energy reserves and to sustain life $[8,9]$.

However, plant feeding by Anopheles gambiae s.s. on host plants is known to occur in a discriminative manner [10-12]. It is commonly known that host plants are sought for sugar and from an evolutionary perspective, those with high sugar content are likely to be more attractive than their counterparts with lower sugar content. However, the association between the sugar content and plant attractiveness to this mosquito vector remains equivocal. Manda et al., [11] showed that there was correlation in the sugar content and the degree of attractiveness of An. gambiae to preferred plant species: Tecoma stans, S. didymobotrya, $R$. communis and Hamelia patens, but not P. hysterophorus. Nonetheless, a related study showed that the attractiveness of An. gambiae to P. hysterophorus was not only related to volatile compounds produced by this plant but to higher sugar levels $[10,13]$. Regardless of plant sugar content, these findings suggest that plant feeding may play other important roles in the life of this mosquito vector.

To expand on an earlier study which reported the attraction of An. gambiae to three host plants; P. hysterophorus, B. pilosa and R. coummunis [10], we have evaluated the extracts of these plants for their toxicity and larvicidal activity. We also included three plants (T. diversifolia, S. didymobotrya, A. afra) of ethnobotanical and medicinal values commonly used in the treatment of malaria in Kenya and two compounds isolated from R. communis. Additionally, Azadiractin indica A. Juss. was included as a positive control because of its known broad spectrum bioactivity against a wide range of insects.

\section{Methods}

Plant materials

P. hysterophorus (Asteraceae, Voucher No. SW00010), T. diversifolia (Asteraceae, Voucher No. SW00015), B. pilosa (Asteraceae, Voucher No. SW00005), and R. communis (Euphorbiaceae, Voucher No. SW00013) were all collected from Nairobi county $\left(1^{\circ} 13^{\prime} 23.46^{\prime \prime}\right.$ S, 36 $53^{\circ}$ 46.83" E), Kenya in April 2011. S. didymobotrya was collected from Laikipia County $\left(0^{\circ} 01^{\prime} 39.43^{\prime \prime} \mathrm{N} 37^{\circ} 03^{\prime} 38.23^{\prime \prime}\right.$ E), Kenya (Leguminosae, Voucher No. SW00018) and $A$. afra (Asteraceae, Voucher No. SW00021) from Meru county $\left(0^{\circ} 09^{\prime} 17.75^{\prime \prime} \mathrm{N} 37^{\circ} 39^{\prime} 37.23^{\prime \prime}\right.$ E), Kenya in July 2012. A. indica (neem) (Meliaceae, Voucher No. SW00023) was collected from Kwale county $\left(4^{\circ} 16^{\prime} 45.83^{\prime \prime} \mathrm{S} 39^{\circ} 35^{\prime}\right.$ 37.38" E), Kenya in December 2012. The plants were authenticated by a botanist and voucher specimen preserved at the National Museums of Kenya, Nairobi. A. indica was selected as a positive control because it has broad spectrum bioactivity against a wide range of insects and parasites including An. gambiae [14-16].

\section{Extraction}

The fresh leaves ( $250 \mathrm{~g}$ each) of seven plants species listed in Table 1 were crushed in a mortar with a pestle to form a paste. The paste was then extracted with $750 \mathrm{~mL}$ of methanol (Analytical grade, Fluka) for $72 \mathrm{~h}$, and then filtered. The procedure was repeated three times and the

Table 1 List of selected plant species

\begin{tabular}{llll}
\hline Botanical name & Voucher specimen number & Common name & Family \\
\hline Artemisia afra Jacq. ex Willd. & SW00021 & Wormwood & Asteraceae \\
Bidens pilosa $\mathrm{L}$. & SW00005 & Black jack & Asteraceae \\
Parthenium hysterophorus L & SW00010 & Wild quinine & Asteraceae \\
Tithonia diversifolia Hemsl. & SW00015 & Mexico sunflower & Asteraceae \\
Ricinus communis L. & SW00013 & Castor oil bean & Euphorbiaceae \\
Senna didymobotrya Fresen & SW00018 & African senna & Leguminosae \\
Azadirachta indica A. Juss. (neem) & SW00023 & Mwarubaini & Meliaceae \\
\hline
\end{tabular}


filtrate evaporated to dryness under vacuum. The concentrated extracts were stored at $-20^{\circ} \mathrm{C}$ until needed for bioassays.

\section{Isolation and identification of compounds from R. communis}

$R$. communis gave the highest bioactivity against both adult females and larvae of An. gambiae s.s, therefore, compounds were isolated from this plant. The methanol extract of $R$. communis was subjected to vacuum liquid chromatography using silica gel (0.032-0.062 mm, Sigma aldrich) eluting with hexane, ethyl acetate, methanol and water. Three fractions were obtained. Fraction 2 was subjected to repeated column chromatography eluting with ethyl acetate, methanol and water and this yielded two pure compounds identified by LC-MS as ricinine and 3-carboxy-4-methoxy-N-methyl-2-pyridone. The LC-MS analysis was carried out on an Agilent 1100 HPLC system (Agilent Technologies, USA), equipped with a Spectra System Pump P4000, an on-line degasser, an auto-sampler AS3000, a column oven temperature of $60^{\circ} \mathrm{C}$, and an ultraviolet detector UV6000LP coupled with a XCalibur software version 2.0 SUR1 (Agilent Technologies, USA). The separation was carried out on a Varian PLRP-S $100 \AA$ polymer column $(4.6 \mathrm{~mm} \times 250 \mathrm{~mm}$, Agilent Technologies, USA) and temperature was set at $60^{\circ} \mathrm{C}$. The mobile phase consisted of $\mathrm{A}: \mathrm{H}_{2} \mathrm{O} \quad 0.1 \%$ Formic acid, B: $90 \%$ $\mathrm{CH}_{3} \mathrm{CN} / \mathrm{H}_{2} \mathrm{O} 0.1 \%$ formic acid at a flow rate of $1 \mathrm{ml} / \mathrm{min}$, split 9:1 after UV detector to give a flow of $100 \mathrm{ul} / \mathrm{min}$ to the LC/MS, using the following gradient elution: $90 \% \mathrm{~A}$ for $2 \mathrm{~min}$, linear gradient to $95 \% \mathrm{~B}$ at $15 \mathrm{~min}$ and at $95 \%$ B for $10 \mathrm{~min}$ followed by $5 \mathrm{~min}$ return to $90 \% \mathrm{~A}$. The injection volume was $20 \mu \mathrm{l}$.

The analysis was performed on a Finnigan LCQ Deca XP Maxi, ion trap mass spectrometer (Thermo Finnigan, USA) connected to the Agilent 1100 HPLC instrument via an electrospray ionization (ESI) interface. The chromatographic conditions were the same as described above. The MS spectra were acquired in both negative and positive modes and full scan mass spectra were acquired from the mass-to-charge ratio $(\mathrm{m} / \mathrm{z})$ of $100-800$. Parameters for
MS were as follows: Aux sweep gas 5 au, ion spray voltage $5 \mathrm{kV}$; capillary temperature $280^{\circ} \mathrm{C}$.

\section{Insects}

Mosquitoes used for the experiments were obtained from established laboratory-reared colonies of An. gambiae s.s. (Mbita strain) at the International Centre of Insect Physiology and Ecology (ICIPE) Duduville campus, Nairobi, Kenya. The strain was initially collected as larvae from anopheline pools at Mbita Point, Suba District, Nyanza County, Western Kenya in April 2011. Larvae were reared in plastic trays $(39 \times 28 \times 14 \mathrm{~cm}$ deep $)$ in an insectary at a density of about 500 larvae per $3 \mathrm{~L}$ of distilled water. The rearing room was maintained at $32 \pm 2^{\circ} \mathrm{C}$, and $52 \%$ relative humidity (R.H.). The larvae were fed daily on (3 mg/larvae/day) Tetramin ${ }^{\oplus}$ fish food (Tetra, Germany). The adult mosquitoes were kept in cubic cages $(30 \times 30 \times 30 \mathrm{~cm})$ in a separate room maintained at $26 \pm 2^{\circ} \mathrm{C}, 70-80 \%$ R.H. with a photoperiod of LD 12:12 $\mathrm{h}$, the light being provided by a fluorescent lamp (40 watt). Both male and female mosquitoes were kept together after emerging and were separated during the assay. Mosquitoes were fed on $6 \%$ glucose solution ad libitum after emergence. The conditions in the bioassay rooms were the same as those of the rearing room.

\section{Toxicity test}

Toxicity tests were carried out using feeding assays. Briefly, two groups of female An. gambiae s.s. (3-5 days old) and previously starved for $12 \mathrm{~h}$ were released into the experimental cages $(15 \times 15 \times 15 \mathrm{~cm})(200 /$ cage $)$ and left to acclimatize for $1 \mathrm{~h}$. One group was fed on the plant extract dissolved in $0.1 \mathrm{~mL}$ of dimethyl sulfoxide (DMSO) and $19.9 \mathrm{~mL}$ of $6 \%$ sugar solution contained in a $20 \mathrm{~mL}$ vial, while the control group fed on a similar extract-free solution. The test extract and control were then introduced into the centre of their respective cages and the mosquitoes fed on the test and control solutions through an immersed rolled up filter paper (Whatman No. 1) with $5 \mathrm{~cm}$ of it exposed above the top of the $20 \mathrm{~mL}$ vial. For the plant extract, five different concentrations; $1,3,5,7$ and $10 \mathrm{mg} / \mathrm{mL}$ of the extract were tested in three

Table 2 Relative toxicity of different plant extracts against female An. gambiae s.s. after 3 days of oral feeding

\begin{tabular}{lllllll}
\hline Plant extract & $\mathbf{X}^{\mathbf{2}}$ & Regression equation & $\mathbf{L C}_{\mathbf{5 0}}(\mathbf{m g} / \mathbf{m L})$ & $\mathbf{L C L}-\mathbf{U C L}(\mathbf{m g} / \mathbf{m L})$ & $\mathbf{L C}_{\mathbf{9 0}}(\mathbf{m g} / \mathbf{m L})$ & $\mathbf{L C L}-\mathbf{U C L}(\mathbf{m g} / \mathbf{m L})$ \\
\hline A. afra & 1.99 & $\mathrm{y}=3.38+1.26 \mathrm{x}$ & 19.56 & $15.93-25.84$ & 204.48 & $119.95-434.91$ \\
B. pilosa & 0.97 & $\mathrm{y}=2.94+1.56 \mathrm{x}$ & 21.09 & $17.31-27.70$ & 140.35 & $87.87-272.85$ \\
P. hysterophorus & 1.76 & $\mathrm{y}=2.35+2.08 \mathrm{x}$ & 18.90 & $15.61-25.44$ & 78.28 & $49.85-161.91$ \\
T. diversifolia & 2.17 & $\mathrm{y}=3.71+1.40 \mathrm{x}$ & 8.30 & $7.53-9.28$ & 67.86 & $50.99-97.14$ \\
R. communis & 3.61 & $\mathrm{y}=2.65+2.14 \mathrm{x}$ & 8.69 & $11.28-14.25$ & 49.53 & $37.89-70.97$ \\
S. didymobotrya & 2.33 & $\mathrm{y}=1.84+2.30 \mathrm{x}$ & 23.39 & $18.29-35.67$ & 84.27 & $50.33-208.19$ \\
A. indica & 1.37 & $\mathrm{y}=3.58+1.51 \mathrm{x}$ & 8.69 & $7.86-9.75$ & 61.17 & $45.68-89.40$ \\
\hline
\end{tabular}

$\mathrm{LC}_{50}$ and $\mathrm{LC}_{90}$ lethal concentration that kills $50 \%$ and $90 \%$ of the ingesting female An. gambiae s.s. respectively, $\mathrm{LCL}$ lower confidence limit, $\mathrm{UCL}$ upper confidence limit based on $95 \%$ Confidence interval, $x^{2}$ chi-square values. 
Table 3 Relative toxicity of different plant extracts against female An. gambiae s.s. after 7 days of oral feeding

\begin{tabular}{lllllll}
\hline Plant extract & $\mathbf{X}^{\mathbf{2}}$ & Regression equation & $\mathbf{L C}_{\mathbf{5 0}}(\mathbf{m g} / \mathbf{m L})$ & $\mathbf{L C L}-\mathbf{U C L}(\mathbf{m g} / \mathbf{m L})$ & $\mathbf{L C}_{\mathbf{9 0}}(\mathbf{m g} / \mathbf{m L})$ & $\mathbf{L C L}-\mathbf{U C L}(\mathbf{m g} / \mathbf{m L})$ \\
\hline A. afra & 7.44 & $\mathrm{y}=4.14+1.38 \mathrm{x}$ & 4.16 & $3.76-4.58$ & 34.91 & $27.85-46.24$ \\
B. pilosa & 66.18 & $\mathrm{y}=2.27+4.01 \mathrm{x}$ & 4.79 & $2.11-6.52$ & 9.99 & $7.18-45.66$ \\
P. hysterophorus & 28.64 & $\mathrm{y}=2.48+3.31 \mathrm{x}$ & 5.74 & $3.76-7.45$ & 13.99 & $9.89-45.50$ \\
T. diversifolia & 11.76 & $\mathrm{y}=4.55+2.39 \mathrm{x}$ & 1.53 & $1.07-1.96$ & 5.23 & $4.19-7.00$ \\
R. communis & 36.02 & $\mathrm{y}=3.47+3.73 \mathrm{x}$ & 2.56 & $1.41-3.40$ & 5.65 & $4.36-8.66$ \\
S. didymobotrya & 30.57 & $\mathrm{y}=1.70+3.60 \mathrm{x}$ & 8.21 & $6.07-13.38$ & 18.61 & $12.12-222.43$ \\
A. indica & 30.04 & $\mathrm{Y}=4.69+2.50 \mathrm{x}$ & 1.34 & $0.67-1.94$ & 4.34 & $3.08-7.29$ \\
\hline
\end{tabular}

$\mathrm{LC}_{50}$ and $\mathrm{LC} 90$ lethal concentration that kills $50 \%$ and $90 \%$ of the ingesting female An. gambiae s.s. respectively, $\mathrm{LCL}$ lower confidence limit, $\mathrm{UCL}$ upper confidence limit based on $95 \%$ Confidence interval, $X^{2}$ chi-square values.

replicates per dose. Daily mortality was recorded in all the mosquito groups for eight consecutive days.

\section{Larvicidal activity}

Larvicidal activity was carried out as described by the WHO [17] with minor modifications as described by Rahuman et al., [18] using third instar larvae. Four different concentrations; $0.125,0.25,0.5$ and $1 \mathrm{mg} / \mathrm{mL}$ were tested. The extracts were prepared in $0.1 \mathrm{~mL}$ of DMSO and $99.9 \mathrm{~mL}$ of distilled water contained in a $250 \mathrm{~mL}$ beaker. This solvent system in a similar ratio served as the control. Three batches of twenty larvae were used for all the experiments and the number of dead larvae in each test was counted and removed after 24, 48 and $72 \mathrm{~h}$ of exposure. The mortality data were subjected to Probit analysis to calculate lethal concentration values $\left(\mathrm{LC}_{50}\right.$ and $\left.\mathrm{LC}_{90}\right)$ and lower and upper 95\% fiducial limits. LC50, LC90 and Chi-square values were calculated using the EPA (U.S. Environmental Protection Agency) computer Probit analysis program (version 1.5).

\section{Survival assay}

Survival tests for the pure isolates from $R$. communis was carried out using the feeding assay described above (see Toxicity test). We aimed to test how the two isolates compared with the crude extract, and in preliminary dose response assays, we found that ricinine at $0.04 \mathrm{mg} / \mathrm{ml}$ was toxic to An. gambiae s.s. adult females.
Therefore, we compared this relatively high dose of ricinine and its derivative 3-carboxy-4-methoxy-N-methyl2-pyridone to that of the crude extract presented to adult female mosquitoes also at this dose. Additionally, two groups of mosquitoes had access to distilled water and $6 \%$ glucose representing negative and positive controls, respectively. Tests were carried out in five replicates. SPSS Advanced Statistics 20.0 was used for data management. Survival was analysed with Kaplan-Meier Model. The mean and median survival time are reported with their 95\% confidence interval (CI). The median survival time is the time at which half of the female Anopheles gambiae died. If the survival curve does not fall to 0.5 (50\%) then the median time cannot be computed as in the case of glucose.

\section{Results}

Toxicity test

Table 2 shows the results of the toxic effects of the different plant extracts against adult females of $A n$. gambiae s.s compared to that of the positive control $A$. indica. Toxicity varied with the plant extract and adult female feeding time. After 3 days of mosquito feeding, the highest mortality was recorded for extracts from $T$. diversifolia and $R$. communis with $\mathrm{LC}_{50}$ values of 8.30 and, $8.69 \mathrm{mg} / \mathrm{mL}$, respectively, which compared to that of the positive control A indica ( $\left.\mathrm{LC}_{50} 8.69 \mathrm{mg} / \mathrm{mL}\right)$. P. hysterophorus, A. afra, $B$. pilosa and $S$. didymobotrya were less toxic with $\mathrm{LC}_{50}$

Table 4 Larvicidal activity of plant extracts against $3^{\text {rd }}$ Instar larvae of An. gambiae s.s. after 24 h of exposure

\begin{tabular}{|c|c|c|c|c|c|c|}
\hline Plant extract & $x^{2}$ & Regression equation & $\mathrm{LC}_{50}(\mathrm{mg} / \mathrm{mL})$ & LCL-UCL(mg/mL) & $\mathrm{LC}_{90}(\mathrm{mg} / \mathrm{mL})$ & $\mathrm{LCL}-\mathrm{UCL}(\mathrm{mg} / \mathrm{mL})$ \\
\hline A. afra & 3.03 & $y=5.03+2.07 x$ & 0.96 & $0.75-1.44$ & 4.01 & $2.34-10.83$ \\
\hline B. pilosa & 0.81 & $y=5.26+1.25 x$ & 0.62 & $0.45-1.02$ & 6.54 & $2.77-47.25$ \\
\hline P. hysterophorus & 3.52 & $y=4.61+1.41 x$ & 1.88 & $1.13-6.17$ & 15.21 & $5.04-250.69$ \\
\hline T. diversifolia & 2.73 & $y=5.35+2.63 x$ & 0.74 & $0.62-0.94$ & 2.27 & $1.60-4.04$ \\
\hline R. communis & 0.79 & $y=6.13+2.87 x$ & 0.40 & $0.35-0.47$ & 1.13 & $0.89-1.59$ \\
\hline S. didymobotrya & 0.52 & $y=5.86+3.08 x$ & 0.53 & $0.46-0.62$ & 1.37 & $1.08-1.97$ \\
\hline A. indica & 0.67 & $y=5.899+2.54 x$ & 0.44 & $0.38-0.53$ & 1.41 & $1.06-2.18$ \\
\hline
\end{tabular}

$\mathrm{LC}_{50}$ and $\mathrm{LC}_{90}$ lethal concentration that kills $50 \%$ and $90 \%$ of $A n$. gambiae s.s. larvae exposed to the extracts, $\mathrm{LCL}$ lower confidence limit, UCL upper confidence limit based on $95 \%$ Confidence interval, $x^{2}$ chi-square values. 
Table 5 Larvicidal activity of plant extracts against $3^{\text {rd }}$ Instar larvae of An. gambiae s.s. after $72 \mathrm{~h}$ of exposure

\begin{tabular}{lllllll}
\hline Plant extract & $\mathbf{X}^{\mathbf{2}}$ & Regression equation & $\mathbf{L C}_{\mathbf{5 0}}(\mathbf{m g} / \mathbf{m L})$ & $\mathbf{L C L}-\mathbf{U C L}(\mathbf{m g} / \mathbf{m L})$ & $\mathbf{L C}_{\mathbf{9 0}}(\mathbf{m g} / \mathbf{m L})$ & $\mathbf{L C L}-\mathbf{U C L}(\mathbf{m g} / \mathbf{m L})$ \\
\hline A. afra & 3.074 & $y=6.98+2.94 x$ & 0.21 & $0.18-0.25$ & 0.58 & $0.47-0.78$ \\
B. pilosa & 1.75 & $y=7.10+3.08 x$ & 0.21 & $0.18-0.24$ & 0.54 & $0.45-0.72$ \\
P. hysterophorus & 0.15 & $y=6.44+2.09 x$ & 0.21 & $0.16-0.25$ & 0.84 & $0.63-1.33$ \\
T. diversifolia & 3.49 & $y=6.94+4.00 x$ & 0.33 & $0.29-0.37$ & 0.68 & $0.58-0.86$ \\
R. communis & 0.91 & $y=8.17+4.21 x$ & 0.18 & $0.15-0.20$ & 0.36 & $0.30-0.45$ \\
S. didymobotrya & 2.98 & $y=6.93+3.36 x$ & 0.27 & $0.23-0.30$ & 0.64 & $0.53-0.83$ \\
A. indica & 2.758 & $y=7.00+2.73 x$ & 0.19 & $0.15-0.22$ & 0.55 & $0.44-0.75$ \\
\hline
\end{tabular}

$\mathrm{LC}_{50}$ and $\mathrm{LC}_{90}$ lethal concentration that kills $50 \%$ and $90 \%$ of An. gambiae s.s. larvae exposed to the extracts, $\mathrm{LCL}$ lower confidence limit, UCL upper confidence limit based on $95 \%$ Confidence interval, $x^{2}$ chi-square values.

values of $18.90,19.56,21.09$ and $23.39 \mathrm{mg} / \mathrm{mL}$ respectively. Toxicity of the different extracts increased with increasing mosquito feeding time, but the pattern of toxicity observed across the different plant extracts after 7 days remained virtually the same with $T$. diversifolia and $R$. communis recording the highest mortality with $\mathrm{LC}_{50}$ values of 1.53 and, $2.56 \mathrm{mg} / \mathrm{mL}$, respectively. T. diversifolia compared well with $A$. indica $\left(\mathrm{LC}_{50} 1.34 \mathrm{mg} / \mathrm{mL}\right)$. A. afra, $B$. pilosa, $P$. hysterophorus and $S$. didymobotrya were less toxic with $\mathrm{LC}_{50}$ values of 4.16, 4.79, 5.74 and $8.21 \mathrm{mg} / \mathrm{mL}$ respectively (Table 3 ).

\section{Larvicidal activity}

Tables 4 and 5 summarize the dose-dependent larvicidal activity of the plant extracts against third-instar larvae of An. gambiae s.s. after $24 \mathrm{~h}$ and $72 \mathrm{~h}$, respectively. The mortality of larvae varied with the plant extract and larval exposure time. After $24 \mathrm{~h}$ of larval exposure, the highest mortality was recorded for extracts from $R$. communis with $\mathrm{LC}_{50}$ values of $0.40 \mathrm{mg} / \mathrm{mL}$, which was in the same

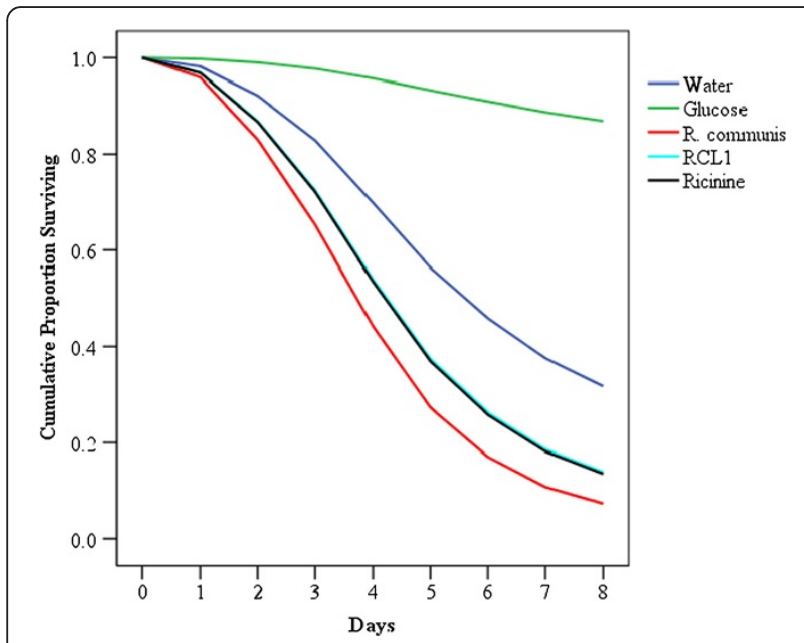

Figure 1 Survival curves of female An. gambiae s.s. on exposure to $R$. communis extract, 3-carbonitirle -4-methoxy-N-methyl-2pyridone (ricinine), 3-carboxy-4-methoxy-N-methyl-2-pyridone (RCL1), distilled water and $6 \%$ glucose. range as the positive control $A$ indica $\left(\mathrm{LC}_{50} 0.44 \mathrm{mg} / \mathrm{mL}\right)$. S. didymobotrya, B. pilosa, T. diversifolia, $A$. afra and $P$. hysterophorus caused low mortality with $\mathrm{LC}_{50}$ values ranging between 0.53 and $1.88 \mathrm{mg} / \mathrm{mL}$ respectively. The larvicidal activity of the different extracts increased with increasing larval exposure time, however, the pattern of activity observed across the different plant extracts after $72 \mathrm{~h}$ remained the same with $R$. communis recording the highest mortality with $\mathrm{LC}_{50}$ values of $0.18 \mathrm{mg} / \mathrm{mL}$ followed closely by $B$. pilosa, $A$. afra and $P$. hysterophorus all the three with $\mathrm{LC}_{50}$ values of $0.21 \mathrm{mg} / \mathrm{mL}$ which were on the same range with positive control $A$ indica $\left(\mathrm{LC}_{50} 0.19 \mathrm{mg} /\right.$ $\mathrm{mL})$. S. didymobotrya and T. diversifolia caused the lowest mortality with $\mathrm{LC}_{50}$ values of 0.27 , and $0.33 \mathrm{mg} / \mathrm{mL}$ respectively.

\section{Survival tests}

Figure 1 shows survival curves of female An. gambiae exposed to $R$. communis extract, 3-carboxy-4-methoxy$\mathrm{N}$-methyl-2-pyridone, ricinine, distilled water and $6 \%$ glucose. The glucose-fed group had the longest overall survival, with mean survival time of $7.65 \pm 0.04$ days (Figure 1, Table 6). The water-fed group gave the next longest survival time of $5.79 \pm 0.07$ days. Mosquitoes fed on 3-carboxy-4-methoxy-N-methyl-2-pyridone and ricinine survived almost as long as those fed on the R. communis extract with mean survival of $4.93 \pm 0.07,4.85 \pm 0.07$ and $4.50 \pm 0.05$ days respectively (Table 6).

\section{Identification of compounds}

Ricinine: this compound was obtained as white crystals. The mass spectrum showed the $\mathrm{M}+1$ peak (base peak) at $\mathrm{m} / \mathrm{z} 165\left(\mathrm{C}_{8} \mathrm{H}_{8} \mathrm{~N}_{2} \mathrm{O}_{2}^{+}\right)$. The other prominent peaks were those at $\mathrm{m} / \mathrm{z} 149\left(\mathrm{C}_{7} \mathrm{H}_{5} \mathrm{~N}_{2} \mathrm{O}_{2}^{+}\right), 138\left(\mathrm{C}_{7} \mathrm{H}_{8} \mathrm{NO}_{2}^{+}\right)$and $109\left(\mathrm{C}_{6} \mathrm{H}_{7} \mathrm{NO}^{+}\right)$. This was compared with the literature and confirmed that the compound was ricinine, having similar fragments.

3-carboxy-4-methoxy-N-methyl-2-pyridone: this compound is reported for the first time in $R$. communis. It was obtained as white powder which dissolved in methanol and sparingly in acetone. The mass spectrum showed the 
Table 6 Mean and median survival times of female Anopheles gambiae maintained on $0.04 \mathrm{mg} / \mathrm{ml}$ of different samples

\begin{tabular}{lllll}
\hline Diet & Mean \pm SE (days) & $\mathbf{9 5 \% ~ C I ~ L C L - U C L ~}$ & Median \pm SE (days) & 95\% Cl LCL-UCL \\
\hline Water & $5.79 \pm 0.07$ & $5.65-5.92$ & $6.00 \pm .014$ & $5.72-6.28$ \\
Glucose & $7.65 \pm 0.04$ & $7.58-7.73$ &. &. \\
R. communis & $4.50 \pm 0.05$ & $4.40-4.60$ & $5.00 \pm 0.06$ & $4.89-5.11$ \\
RCL1 & $4.93 \pm 0.07$ & $4.80-5.06$ & $5.00 \pm 0.10$ & $4.81-5.19$ \\
Ricinine & $4.85 \pm 0.07$ & $4.71-4.99$ & $4.00 \pm 0.11$ & $3.78-4.22$ \\
\hline
\end{tabular}

$\mathrm{SE}$, standard error; $\mathrm{Cl}, 95 \%$ confidence interval, LCL- lower confidence limit, UCL- upper confidence limit, RCL1- 3-carboxy-4-methoxy-N-methyl-2-pyridone.

$\mathrm{M}+\mathrm{CH}_{2}$ peak at $\mathrm{m} / \mathrm{z} 197\left(\mathrm{C}_{9} \mathrm{H}_{11} \mathrm{NO}_{4}^{+}\right)$. The molecular ion peak was observed at $\mathrm{m} / \mathrm{z} 183\left(\mathrm{C}_{8} \mathrm{H}_{9} \mathrm{NO}_{4}^{+}\right)$. Other prominent peaks were those at $\mathrm{m} / \mathrm{z} 166$ (base peak) $\left(\mathrm{C}_{8} \mathrm{H}_{8} \mathrm{~N}_{2} \mathrm{O}_{3}^{+}\right), \quad 139\left(\mathrm{C}_{7} \mathrm{H}_{9} \mathrm{NO}_{2}^{+}\right)$and $109\left(\mathrm{C}_{6} \mathrm{H}_{7} \mathrm{NO}^{+}\right)$. Figure 2 provides the possible fragmentation pattern for this molecule to justify some of the observed peaks in the mass spectrum.

\section{Discussion}

Plant extracts may exhibit varying bioactivity on insects. This study showed that of the six extracts evaluated, those from $T$. diversifolia, and $R$. communis caused the highest mortality in females of An. gambiae. Previous studies have reported the presence of sesquiterpene lactones in $T$. diversifolia and alkaloids in $R$. communis $[19,20]$. These two classes of compounds are known to exhibit a wide range of biological activity including against insect vectors [21,22], which may explain the observed effect of these two plants. Indeed, the toxic effects of extracts from these two plants were comparable to that of the positive control, $A$. indica, which is known to contain limonoids, well known as anti-insect compounds and found to be effective against the mosquitoes Aedes aegypti and An. gambiae [23-26]. The differential mortality effect observed for the plants evaluated especially among those known to be attractive to this vector justifies the fact that plant feeds may have additional effects on this mosquito and are important not only for sugars. Therefore, the higher activity found for extracts from $T$. diversifolia and $R$. communis relative to the other related Asteraceae plants and for the other families could be due to differences in the secondary metabolites present in the different plants.

We observed a relatively high larvicidal activity of the extract from $R$. communis compared to the extracts from the other five plants, a finding which is in agreement with a previous study, which showed effectiveness of the extract from this plant with potent mosquito larvicidal acitivity against larvae of Anopheles arabiensis [27]. In contrast, we observed a rather weak larvicidal activity of T. diversifolia extracts. Although the reason for this observation is unclear, it could be related to the low concentration of the extract from this plant tested in this study as a previous study showed high activity against Aedes aegypti at higher doses $>50 \mathrm{mg} / \mathrm{mL}$ tested [28].

The influence of exposure time on mosquito survival was linked to the amount of test material consumed, which varied depending upon the sample. The group of mosquitoes feeding on glucose, as expected survived the longest period followed by those fed on water. Interestingly, our results show that the pattern of survival on the extract from $R$. communis and the two pure isolates

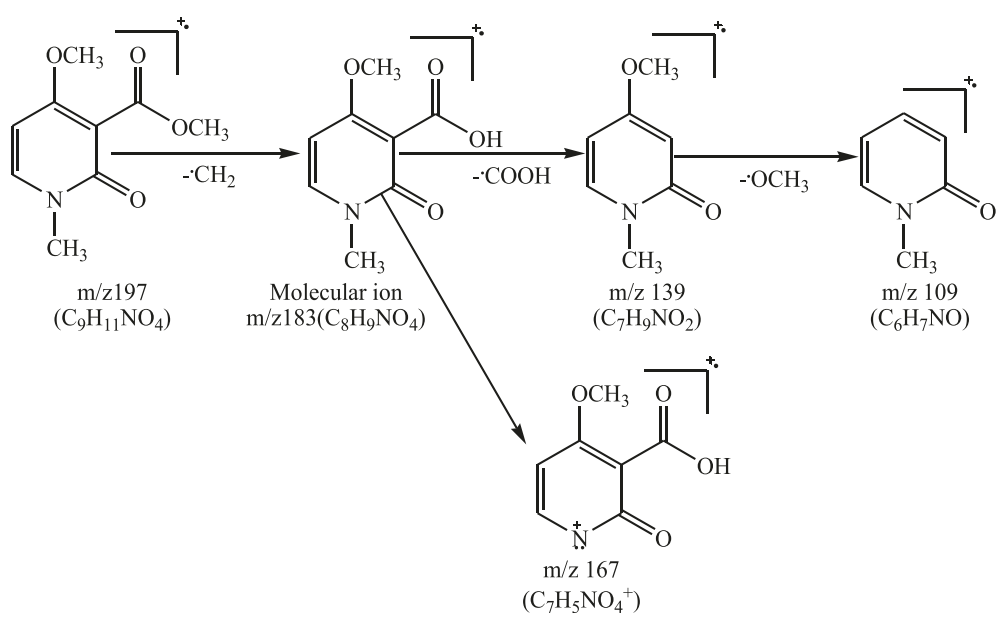

Figure 2 Fragmentation pattern for 3-carboxy-4-methoxy-N-methyl-2-pyridone. 
from this plant was similar. They all lowered the survival of mosquitoes, which decreased with time compared to those fed on glucose and water only. The survival of mosquitoes on the two isolates from $R$. communis was superimposable on one another suggesting that substitution at the 3-position with a carbonitrile or carboxylic acid did not affect the activity of the alkaloid. Thus activity of the alkaloid may involve other moieties or the combined effect of several of these spread across the molecule. It is worthy to note that the crude extract was slightly more active than the individual isolates suggesting that other minor components in the extract could play a role in the overall activity of the extract.

\section{Conclusion}

We conclude that, of the six plants, extracts from $T$. diversifolia and $R$. communis could serve as useful candidate insecticides against larvae and adult females of $A n$. gambiae s.s. since they showed the highest bioactivity.

\section{Competing interests}

The authors declare that they have no competing interests.

\section{Authors' contributions}

SWW \& BT conceived and designed the study. SWW, JW, MW performed the experiments and SWW analyzed the data. SWW, SO, DM, DS, AH, BT wrote the paper. All authors approved the final version for submission.

\section{Acknowledgements}

We are grateful to the staff at the International Centre of Insect Physiology and Ecology (ICIPE), Duduville, Nairobi, who provided support without which our research would not have been possible and Komivi Akutse for guidance on data analysis. Special thanks are extended to David Tchouassi and Vincent Nyasembe for helpful comments on the manuscript and Richard Ochieng and Milcah Gitau for their technical support. We thank Simon Mathenge (formerly of the Botany Department, University of Nairobi) for help in identification of plants. The work was supported by Training Health Researchers into Vocational Excellence (THRiVE) in East Africa, Grant number 087540, funded by Wellcome Trust. Its contents are solely the responsibility of the authors and do not necessarily represent the official views of the supporting offices.

\section{Author details}

International Centre of Insect Physiology and Ecology, P.O. Box 30772-00100, Nairobi, Kenya. 'Kenya Medical Research Institute, Centre for Traditional Medicine and Drug Research, P. O. Box 54840-00200, Nairobi, Kenya. ${ }^{3}$ Kenya Medical Research Institute, Centre for Biotechnology Research Development, P.O Box 54840-00200, Nairobi, Kenya. ${ }^{4}$ Institute of Tropical Medicine and Infectious Diseases (ITROMID), Jomo Kenyatta University of Agriculture and Technology, P.O. Box 62000-00200, Nairobi, Kenya. ${ }^{5}$ USDA/ ARS-CMAVE, 1700 SW 23rd Dr., Gainesville, FL, USA. ${ }^{6}$ Chemistry Department, University of Cambridge, Lensfield Road, Cambridge CB2 1EW, UK.

Received: 5 May 2014 Accepted: 28 June 2014

Published: 4 July 2014

\section{References}

1. World Health Organization: Malaria Fact Sheet; 2013. N94. http://www.who int/mediacentre/factsheets/fs094/en/.

2. World Health Organization: Global Report on Antimalarial Efficacy and Drug Resistance. Geneva: WHO Press; 2000-2010:6-86.

3. Noedl HD, Se Y, Schaecher K, Smith BL: Evidence of artemisinin-resistant malaria in Western Cambodia. New Engl J Med 2008, 361:2619-2620.

4. Dondorp AM, Nosten F, Yi P, Das D, Phyo AP, Tarning J, Lwin KM, Ariey F, Hanpithakpong W, Lee SJ, Ringwald P, Silamut K, Imwong M, Chotivanich K, Lim P, Herdman T, An SS, Yeung S, Singhasivanon P, Day NP, Lindegardh N,
Socheat $D$, White NJ: Artemisinin resistance in Plasmodium falciparum malaria. New Engl J Med 2009, 361:455-467.

5. Satimai W, Sudathip P, Vijaykadga S, Khamsiriwatchara A, Sawang S, Potithavoranan T, Sangvichean A, Delacollette C, Singhasivanon P, Kaewkungwal J, Lawpoolsri S: Artemisinin resistance containment project in Thailand: II: responses to mefloquine-artesunate combination therapy among falciparum malaria patients in provinces bordering Cambodia. Malar J 2012, 11:300.

6. Coetzee M, Craig M, Le Sueur D: Distribution of African malaria mosquitoes belonging to the Anopheles gambiae complex. Parasitol Today 2000, 16:74-77.

7. Coetzee M: Distribution of the African malaria vectors of the Anopheles gambiae complex. Am J Trop Med Hyg 2004, 70:103-104.

8. Foster WA: Mosquito sugar feeding and reproductive energetics. Ann Review Entomol 1995, 40:443-474

9. Foster WA, Takken W: Nectar-related vs. human related volatiles: behavioural response and choice by female and male Anopheles gambiae (Diptera: Culicidae) between emergence and first feeding. Bull Entomol Res 2004, 94:145-157.

10. Nyasembe VO, Teal EAP, Mukabana WR, Tumlinson JH, Torto B: Behavioural response of the malaria vector Anopheles gambiae to host plant volatiles and synthetic blends. Parasit Vectors 2012, 5:234.

11. Manda H, Gouagna LC, Nyandat E, Kabiru EW, Jackson RR, Foster WA, Githure JI, Beier JC, Hassanali A: Discriminative feeding behaviour of Anopheles gambiae s.s. on endemic plants in western Kenya. Med Vet Entomol 2007, 21:103-111.

12. Manda H, Gougna LC, Foster WA, Jackson RR, Beier JC, Githure JA, Hassanali A: Effect of discriminative plant-sugar feeding on the survival and fecundity of Anopheles gambiae. Malar J 2007, 6:113.

13. Nyasembe VO, Tchouassi DP, Kirwa HK, Foster WA, Teal PEA, Borgemeister C, Torto B: Development and assessment of plant-based synthetic odor baits for surveillance and control of malaria vectors. PLoS One 2014, 9:e89818.

14. Mordue (Luntz) AJ, Morgan ED, Nisbet AJ: Azadirachtin, A Natural Product in Insect Control. In Comprehensive Molecular Science, 6. Edited by Gilbert LI, latrou K, Gill SS. Oxford: Elsevier; 2005:117-135.

15. Ndione RD, Faye O, Ndiaye M, Afoutou JM: Toxic effects of neem products (Azadirachta indica A. Juss) on Aedes aegypti Linnaeus 1763 larvae. Afric J Biotech 2007, 6:2846-2854.

16. Okumu FO, Knols BGJ, Fillinger U: Larvicidal effects of a neem (Azadirachta indica) oil formulation on the malaria vector Anopheles gambiae. Malar J 2007, 6:63-67.

17. WHO: Guidelines for laboratory and field testing of mosquito larvicides. WHO/ CDS/WHOPES/GCDPP/2005.13.

18. Rahuman AA, Venkatesan P, Gopalakrishnan G: Mosquito larvicidal activity of oleic and linoleic acids isolated from Citrullus colocynthis Linn. Schrad Parasitol Res 2008, 1036:1383-1390.

19. Pereira PS, Dias DA, Vichnewski W, Nasi AMTT, Herz W: Sesquiterpene lactones from Brazilian Tithonia diversifolia. Phytochem 1997. 45:1445-1448

20. Kang SS, Cordell GA, Soejarto DD, Fong HHS: Alkaloids and flavonoids from Ricinus communis. J Nat Prod 1985, 48:155-156.

21. Picman AK: Biological activities of sesquiterpene lactones. Biochem Syst Ecol 1986, 14:255-281.

22. Mann RS, Kaufman PE: Natural products pesticides: their development delivery and use against insects vectors. Mini-Rev Org Chem 2012, 9:185-202.

23. Kubo I, Matsumoto A, Matsumoto T: New insect ecdysis inhibitory limonoid deacetylazadirachtinol isolated from Azadirachta indica (meliaceae) oil. Tetrahed 1986, 42:489-496.

24. Schmutterer $\mathrm{H}$ : Properties and potential of natural pesticides from the Neem Tree, Azadirachta indica. Ann Rev Entomol 1990, 35:271-297

25. Roy A, Saraf S: Limonoids: overview of significant bioactive triterpenes distributed in plants kingdom. Biol Pharm Bull 2006, 29:191-201

26. Kiprop AK, Kiprono CP, Rajab MS, Kosgei KM: Limonoids as larvicidal components against mosquito larvae (Aedes aegypti Linn). Z Naturforsh 2007, 62:826-828.

27. Elimam AM, Elmalik KH, Ali FS: Larvicidal, adult emergence inhibition and oviposition deterrent effects of foliage extract from Ricinus 
communis L. against Anopheles arabiensis and Culex quinquefasciatus in Sudan. Trop Biomed 2009, 26:130-139.

28. Langat KB, Siele KD, Nanyingi OM, Mutai KC, Rukunga MG, Mwandawiro C, Ireri L, Tonui KW: Larvicidal action of extracts from Tithonia diversifolia against the dengue mosquito Aedes aegypti(Diptera: Culicidae). J Biologic Active Prod Nat 2012, 2:46-49.

doi:10.1186/1756-3305-7-312

Cite this article as: Wachira et al:: Toxicity of six plant extracts and two pyridone alkaloids from Ricinus communis against the malaria vector Anopheles gambiae. Parasites \& Vectors 2014 7:312.

\section{Submit your next manuscript to BioMed Central and take full advantage of:}

- Convenient online submission

- Thorough peer review

- No space constraints or color figure charges

- Immediate publication on acceptance

- Inclusion in PubMed, CAS, Scopus and Google Scholar

- Research which is freely available for redistribution 